\title{
WestVirginiaUniversity
}

THE RESEARCH REPOSITORY @ WVU

Graduate Theses, Dissertations, and Problem Reports

2013

\section{Korean Violinist Min Kim: His Devotion to and Achievements in Chamber Music}

Seung Hee Yeo

West Virginia University

Follow this and additional works at: https://researchrepository.wvu.edu/etd

\section{Recommended Citation}

Yeo, Seung Hee, "Korean Violinist Min Kim: His Devotion to and Achievements in Chamber Music" (2013). Graduate Theses, Dissertations, and Problem Reports. 141.

https://researchrepository.wvu.edu/etd/141

This Dissertation is protected by copyright and/or related rights. It has been brought to you by the The Research Repository @ WVU with permission from the rights-holder(s). You are free to use this Dissertation in any way that is permitted by the copyright and related rights legislation that applies to your use. For other uses you must obtain permission from the rights-holder(s) directly, unless additional rights are indicated by a Creative Commons license in the record and/ or on the work itself. This Dissertation has been accepted for inclusion in WVU Graduate Theses, Dissertations, and Problem Reports collection by an authorized administrator of The Research Repository @ WVU.

For more information, please contact researchrepository@mail.wvu.edu. 


\title{
Korean Violinist Min Kim: \\ His Devotion to and Achievements in Chamber Music
}

\author{
Seung Hee Yeo \\ A Doctoral Research Project Submitted to \\ the College of Creative Arts \\ at \\ West Virginia University \\ in partial fulfillment of the requirements for the degree of
}

Doctor of Musical Arts

in

Violin Performance

Mikylah Myers McTeer, D.M.A., Chair and Research Advisor

William Skidmore, M.M.

Andrew Kohn, Ph.D.

Peter Amstutz, D.M.A.

Ju-Hyeong Park, Sc.D.

School of Music

Morgantown, West Virginia

2013

Keywords: Min Kim, Korean Violinist, Violin Lineage in Korea, Korean

Chamber Orchestra

Copyright 2013 Seung Hee Yeo 


\section{Abstract \\ Korean Violinist Min Kim: His Devotion to and Achievements in Chamber Music \\ Seung Hee Yeo}

Western music in Korea has barely a one hundred-year history, and it developed particularly rapidly after the Korean War (1950-1953) as the economy began to grow. In the present day, many Koreans have been trained as professional musicians. Despite the individual successes of Korean musicians, there have been few Korean ensembles that have gained international renown.

The purpose of this study is to provide a complete overview of the Korean violinist Min Kim, including his biography, teaching, and especially his great influence on and achievements in chamber music in Korea. The main sources of material for this study are interviews with Min Kim and several of his pupils, conducted by the author, and articles in journals which were written based on interviews with Kim. Previously published interviews with Kim have been translated from Korean to English by the author. It also presents a general overview of the history of the violin in Korea. The study consists of five chapters: (1) Introduction, (2) A musical history of the violin in Korea, (3) Korean violinist Min Kim, (4) Kim as a director and leader of the Korean Chamber Orchestra, and (5) Conclusion.

Min Kim (1942-) is one of the most influential violinists in Korea, and he is considered to be the leader of the fourth generation of great violinists in the country. After studying at Seoul National University, he went to Germany to study as a Deutscher Akademischer Austauschdienst (DAAD, German Academic Exchange Service) student in 1969, where he had various musical experiences, especially as a chamber and orchestral musician. In 1979, Kim returned from Germany, and began to share his musical experiences with the next generation of Korean musicians. He especially contributed many achievements in the development of chamber music in Korea. Kim devoted most of his musical life to the Korean Chamber Orchestra, which was founded in 1965 by cellist Bong Cho Jeon (1919-2002), and disbanded in 1975. In 1979, Kim reorganized the ensemble, and it gave a second debut concert in 1980. Since then, the ensemble has given approximately five hundred concerts in Korea and other countries around the world.

The primary finding of this study is that Min Kim had a great influence on the development of Western music in Korea, especially on violin and chamber music. There is no doubt that Kim was one of the most important pioneers of chamber music in Korea, and that he and the Korean Chamber Orchestra enabled chamber music to become firmly rooted in the country. Subsequent generations should continue studying and performing chamber music in order to further develop the country's musical tradition. 


\section{Acknowledgements}

I am deeply grateful to Dr. Mikylah McTeer, my violin teacher, committee chair, and research advisor, for her support, insightful thoughts, and guidance. I would like to thank my committee members, Professor William Skidmore, Dr. Andrew Kohn, Dr. Peter Amstutz, and Dr. Ju-Hyeong Park, for their assistance and comments.

Special thanks go to my former Professor in Korea Kyung Hee Yoon, a pupil of Professor Min Kim, who helped this research project to be possible and arranged all of the necessary interviews, including those with Professor Kim and his pupils; I am very thankful to Professor Min Kim, Professor Ji Yoon Ahn, Professor Jae Won Ryu, and Professor Jae Won Choi, for granting interviews for the project.

Finally, thank you to my parents for their endless support and encouragement in all circumstances. 


\section{Table of Contents}

Chapter 1: Introduction........................................................1

Purpose of the Study............................................................

Outline of the Study........................................................

Review of Literature..........................................................

Chapter 2: A Musical History of the Violin in Korea..............................5

The Introduction of Western Music to Korea........................................

Violin Lineage in Korea....................................................... 8

The First Generation of Korean Violinists..................................8

The Second Generation of Korean Violinists................................10

The Third Generation of Korean Violinists................................. 12

The Fourth Generation of Korean Violinists................................... 14

Chapter 3: Korean Violinist Min Kim..........................................18

Background and Musical Education............................................. 18

Early Life...................................................... 18

Interests in Chamber Music..............................................20

Life in Germany..................................................22

Teaching at Seoul National University.......................................... 24

As a Dean of the College of Music at Seoul National University...............27

\section{Chapter 4: Kim as a Director and Leader of the Korean Chamber}

Orchestra...............................................................................29

The Korean Chamber Orchestra................................................29

Other Musical Activities of the Korean Chamber Orchestra....................40

As a Chamber Musician....................................................42

Chapter 5: Conclusion.....................................................................44

Bibliography..............................................................50 


\section{Chapter 1}

\section{Introduction}

\section{Purpose of the Study}

Western music in Korea has barely a one hundred-year history, and it developed particularly rapidly after the Korean War (1950-1953) as the economy began to grow. In the present day, most children learn Western music in public schools, and can play at least one instrument. Many Koreans have been trained as professional musicians both in Korea and internationally, and a significant number have acquired worldwide reputations as fine musicians (e.g. pianist and conductor Myung-Whun Chung, and violinists Kyung-Wha Chung and Sarah Chang). Despite the individual successes of Korean musicians, there have been few Korean ensembles that have gained international renown.

The Korean violinist Min Kim (1942-) is one of the most influential violinists in Korea, and he is considered to be the leader of the fourth generation of great violinists in the country. After studying at Seoul National University, he went to Germany to study as a Deutscher Akademischer Austauschdienst (DAAD, German Academic Exchange Service) student in 1969, where he had various musical experiences, especially as a chamber and orchestral musician; for example, he served as the concertmaster and soloist of the Köln Chamber Orchestra and the Berlin Radio Symphony Orchestra. Studying abroad was an unusual opportunity; in the 1960's musicians grew up under poorer conditions, and only a few musicians had the chance to study in another country. ${ }^{1}$ In 1979, Kim returned from Germany to serve as concertmaster of the National

1 Yoon Jo Gong, "Arts, My Life My Way: Violinist Min Kim," Auditorium 112 [June 1993]: 114. 
Symphony Orchestra, which is now known as the KBS (Korean Broadcasting System)

Symphony Orchestra. Here he began to share his musical experiences with the next generation of Korean musicians. He returned to his alma mater to teach violin, and remained in this position for twenty-seven years. Many fine violinists emerged from his studio.

Kim devoted most of his life in music to the Korean Chamber Orchestra, which is considered to be the oldest chamber ensemble in Korea. The Korean Chamber Orchestra was founded in 1965 by cellist Bong Cho Jeon (1919-2002), who at the time was a professor of cello at Seoul National University, where he created a chamber ensemble course. He organized the members based on completion of the ensemble course; Min Kim was among the most impressive of the students, and became the first concertmaster of the ensemble. The ensemble, however, stopped giving concerts in 1975. In 1979, the Korean Chamber Orchestra was revived by Kim after he came back from his studies in Germany; the Orchestra gave a second debut concert in $1980 .^{2}$ Kim has been involved as director and leader until the present day, and the Orchestra has given approximately five-hundred concerts; since its first concerts in Tokyo, Washington DC, and New York City in 1987, the Orchestra has presented more than one hundred concerts outside of Korea. ${ }^{3}$ Because Kim had been such a strong influence on this ensemble, any discussion of his career must focus on the Korean Chamber Orchestra.

The purpose of this study is to provide a complete overview of Min Kim, including his biography, teaching, and especially his great influence on and achievements in chamber music in

\footnotetext{
2 Ji Soo Kim, "The 45th Anniversary, the Korean Chamber Orchestra," String \& Bow, no. 131 [January 2010]: 21.

${ }^{3}$ Korean Chamber Orchestra, "Profile," http://www.kco.or.kr/01-01.htm [accessed September 11, 2012].
} 
Korea. It also provides a general overview of the history of the violin in Korea. It is hoped that this study, through interviews by the author with Min Kim and his pupils and translations of articles previously published only in Korean, will be a valuable source for those who are interested in Korean violin history, in Min Kim, and in the Korean Chamber Orchestra.

\section{Outline of the Study}

The study consists of five chapters: (1) Introduction, (2) A musical history of the violin in Korea, (3) Korean violinist Min Kim, (4) Kim as a director and leader of the Korean Chamber Orchestra, and (5) Conclusion.

The second chapter provides a general overview of the history of the violin in Korea. It provides a brief look at the Korean violin lineage and how it has been developed; a lineage which spans four generations of musicians. The third chapter introduces one of the most influential violinists in Korea - Min Kim - including his background and musical education, and his teaching at Seoul National University. The fourth chapter focuses on him as a director and leader of the Korean Chamber Orchestra and his devotion to and achievements with the Orchestra. The final chapter offers a concluding summary; his influence on the development of Western music - especially on violin and chamber music - has been profound and far-reaching, and will continue to have an impact on the next generations of Korean musicians.

\section{$\underline{\text { Review of Literature }}$}

The resources used in this project were identified through the internet databases RILM Abstracts of Musical Literature, JSTOR, and ProQuest Dissertations and Theses. It was difficult 
to find resources published in English although a few resources were found which related indirectly to the topic, such as a dissertation about Western music in Korea. Much of the research for this paper involves translations from Korean to English, provided by the author. The titles of the materials written in Korean are listed both in the original language and in their English translations in the bibliography section; however, only the English titles are offered in the footnotes.

Most resources for this research paper are articles in journals, which were found at The National Library of Korea and National Assembly Library, both of which are located in Seoul. Most of the articles were written based on interviews with Min Kim, and as such they provide general information including his background, musical education, and his philosophy of music. Many of the articles focus on his devotion to the ensemble and his general achievements in the chamber and orchestral fields, along with the Korean Chamber Orchestra in particular. Interviews with Kim and with others who were influenced by him (e.g. his students) are also included. Those interviews were conducted by the author.

Various books have been found useful as a source of general information about the history of Western music and the violin in Korea (e.g. One Hundred-Year History of Western Music in Korea and The Pioneers to be Remembered: The Historical Figures of Western Music in Korea 1). Even though a number of articles about Min Kim exist, there appear to be no dissertations or books written about him, in either English or Korean. The website of the Korean Chamber Orchestra gives general information about the Orchestra itself. 


\section{Chapter 2}

\section{A Musical History of the Violin in Korea}

\section{The Introduction of Western Music to Korea}

The history of Western music in Korea spans barely one hundred years. There is no conclusive proof regarding the precise time when Western music was introduced in Korea, or who was primarily responsible for introducing it. There are several different opinions on the question of when it was introduced, and through which medium it was introduced (e.g. the spread of Christian hymns, the creation of military bands, Catholic liturgy, etc.). Among these, the view that Western music in Korea was introduced through Christian hymns is generally accepted by many scholars, because foreign missionaries brought not only the Gospel but also Christian hymns to Korea. ${ }^{4}$

Musicologists point to the year 1885 as important in the history of Western music in Korea; in that year, American missionaries Henry Gerhard Appenzeller (1858-1902) and Horace Grant Underwood (1859-1916) came to Korea to introduce and spread Protestantism in the country. They not only spread the Gospel and taught Christian hymns, but they established schools designed for missionary work. The schools made a great contribution to the spread of Western music, especially at Soongsil College (which is now known as Soongsil University), Yonhi College (also called Chosun Christian College, now known as Yonsei University), and

\footnotetext{
${ }^{4}$ Kang Sook Lee, Choon Mi Kim, and Kyung Chan Min, One Hundred-Year History of Western Music in Korea [Seoul: Hyeonamsa, 2001], 16.
} 
Ewha Womans College (known today as Ewha Womans University). ${ }^{5}$ Even though there were no music departments in the colleges of this period, the schools still produced many fine musicians through various musical activities. ${ }^{6}$

A musically-talented missionary named Eli M. Mowry (1880-1971) came to Korea in 1909 and taught biology and English at Soongsil College in Pyongyang (now the capital of North Korea) - the College is now located in Seoul and is known as Soongsil University. Mowry organized a choir and a band at the College, not only for missionary work, but also to give concerts in several cities. In addition to this, Mowry helped to organize church choirs in many churches when he took a tour of various cities for missionary work. ${ }^{7}$ Many great musicians in the future were influenced by the musical environment of the College, including the first pianist in Korea, Young Hwan Kim (1893-1978), composer Dong Jin Kim (1913-2009), and tenor and composer Je Myung Hyun (1902-1960). ${ }^{8}$

In Seoul, Yonhi College and Ewha Womans College made a great contribution to the development of Western music. Western musical opportunities were created for students at Yonhi College through the introduction of a school choir and band. Even though there was not yet a music department at the College, pianist Young Hwan Kim served as head of the music society

\footnotetext{
5 The University must keep using "Woman's" instead of "Women's," even though it is not proper grammar, because the word "Woman's" was chosen to indicate that all Ewha people are respected.

${ }^{6}$ Sang Woo Han, The Pioneers to be Remembered: The Historical Figures of Western Music in Korea 1 [Gyungkido, Korea: Jisik-sanup, 2003], 12.

7 Ibid., 24-25.

8 Ibid., 26.
} 
of the College from 1918 to 1928; he pursued more studies in Japan after finishing his studies at Soongsil College, and under his leadership students began to develop their own musical activities. ${ }^{9}$ Later, Je Myung Hyun, who had studied in the United States of America (USA), and was both a tenor and a well-regarded composer, took the position. Under his leadership, the music society blossomed, giving regular concerts with orchestra starting in $1929 .{ }^{10}$ The future musicians who studied at the College around this time include violinists Hak Joon Moon (c.1915-?) and Hee Seok Jeong (1917-2002), later the dean of the College of Music at Yonsei University, tenor and music critic Yoo Sun Lee (1911-2005), and conductor Saeng Ryeo Kim (1912-1995), who later became a conductor of the Seoul Philharmonic Orchestra. ${ }^{11}$

Ewha Womans College also served an important role in expanding Western music's influence in Korea. This College graduated many fine women musicians, including soprano Sun Yeop Chae (1911-1987) and, pianist Young Eui Kim (1908-1987), later the dean of the College of Music at Ewha Womans University. ${ }^{12}$ The College's musical activities consisted mainly of the women's choir "Glee Club" (which started in 1897 and has continued until now), piano, and vocal music. ${ }^{13}$ The most important musical event at the College was the official opening of Korea's first music department, in 1925.

\footnotetext{
9 Han, The Pioneers to be Remembered: The Historical Figures of Western Music in Korea 1, 29.

10 Ibid., 31.

11 Ibid., 33.

12 Ibid., 38.

13 Ibid., 37-38.
} 
Early instances of Western music consisted mainly of church-related works (e.g.

Christian hymns and church choirs); the study of Western art music for its own sake began in earnest in the 1930s. ${ }^{14}$

\section{$\underline{\text { Violin Lineage in Korea }}$}

\section{The First Generation of Korean Violinists}

There are always great and important pioneers in the development of any field. The development of Western music in Korea is no different, with many pioneering and memorable musicians playing a role. This was particularly true of the great violinists. As shown in Figure 1 "Violin Lineage in Korea" [which spans four generations, and is at the end of this chapter], the first generation of notable Korean violinists is considered to be Nan Pa Hong (1898-1941); Dong Sun Chae (1901-1953), also known as a composer; Jung Sik Gye (1904-1974); Byeong So Ahn (1910-1979); and Young Se Lee (1911-1987).

The first Korean violinist to have formal musical training was Nan Pa Hong (1898-1941), who was also the first composer, conductor, critic and publisher of a music journal in Korea. He studied the violin with In Sik Kim (1885-1962), the first Western music teacher in Korea, at the Western music department of the Korean Court Music Institute (Chosun Jeongak Jeonseupso). ${ }^{15}$ He later pursued more studies in Japan and Chicago. After his return to Korea, Hong taught many students and founded the Nanpa Trio, consisting of three violinists, along with Sung Yoo

\footnotetext{
${ }^{14}$ Han, The Pioneers to be Remembered: The Historical Figures of Western Music in Korea 1, 12.

${ }^{15}$ Ibid., 198-99.
} 
Hong (1908-1936) and Young Se Lee. He achieved successes in many areas of Western music in Korea; however, he is primarily remembered as a composer, especially of art songs.

Another notable violinist from the first generation is Jung Sik Gye (1904-1974), who studied violin in Japan and Germany, and became a professor of violin at Ewha Womans College in 1935. He was a founding member of Koryŏ Philharmonic Orchestra in 1945, along with Je Myung Hyun and Saeng Ryeo Kim. The Koryŏ Philharmonic was the first orchestra in Korea (the Koryŏ Philharmonic later became the Seoul Philharmonic Orchestra) and Gye became its first conductor. Violinists Hee Seok Jeong and Hak Joon Moon studied with him. In 1961, Gye moved to the USA and spent the rest of his life there. ${ }^{16}$

Violinist Byeong So Ahn (1910-1979), who focused only on the violin throughout his musical life, is considered to be the first professional virtuoso violinist in Korea. He studied in Japan and Berlin, where his teacher was Willy Hess (1859-1939), a pupil of Joseph Joachim (1831-1907). Ahn was asked to teach at several colleges after he came back to Korea; however, he refused and gave only private lessons because he believed that "performers must only focus on studying and developing their performance skills." ${ }^{17}$ He was very strict with his students, especially with fingerings and bowings; this teaching seems to have helped each of his students to develop a solid left-hand technique. ${ }^{18}$ His pupils included Chang Hwan Kim (1925-), Hae

\footnotetext{
16 Doopedia, s.v. "Jung Sik Gye," http://www.doopedia.co.kr/doopedia/master/master.do?_method=view\&MAS_IDX=101013000742211 [accessed September 7, 2012].

17 Joo Young Bae, "The First Professional Korean Violinist Byeong So Ahn," The Monthly Music Magazine Eumagchunchu 150 [February 2008]: 86.

18 Ibid., 83-85.
} 
Yeop Yang (1929-), and Woon Chang Paik (1933-).

The world's greatest violinists began to give recitals in Korea during this period. The first foreign violinist to give a recital in Korea was Fritz Kreisler, on May 23, 1923 at the Kyungsung (the former name of what is now Seoul) public hall. Other significant Korean debuts by foreign musicians included Jascha Heifetz on November 5, 1923, Efrem Zimbalist in 1924, Jacques Thibaud in 1933, and Mischa Elman in $1937 .{ }^{19}$

\section{The Second Generation of Korean Violinists}

The violinists often considered to be the greatest musicians of the second generation are Hee Seok Jeong (1917-2002), Hak Joon Moon (c.1915-?), and Min Jong Park (1918-2006).

Violinist Hee Seok Jeong (1917-2002), who was also a conductor and teacher, received his first formal violin lessons from Sung Gyo Ahn (c.1905-c.1953). Since there were not yet any college music departments, except for Ewha Womans College, Jeong later entered Yonhi College, and developed his musical talent in the music society of this institution, under the leadership of Je Myung Hyun. He studied the violin with Jung Sik Gye during this time, and went on to further his musical studies and experiences in Japan. ${ }^{20}$

Jeong returned to Korea and made great contributions to the advancement of orchestral music at Ewha Womans University and Yonsei University. He served Ewha Womans University from 1946 to 1967, and during this time he founded and conducted the orchestra. The orchestra

\footnotetext{
19 Han, The Pioneers to be Remembered: The Historical Figures of Western Music in Korea 1, 17-18.

20 Hye Rim Park, "Violinist Hee Seok Jeong: His Contribution to the Development of Korean Orchestras," The Monthly Music Magazine Eumagchunchu 152 [April 2008]: 81.
} 
not only presented two regular concerts every year, but also gave occasional performances of operas. His passion for orchestral works resulted in the steady improvement of the orchestra's quality. In 1967, Jeong returned to his alma mater, Yonsei University, as a professor of violin (and later the dean of the College of Music at the University), and he also contributed to the orchestra's improvement at that institution, where he taught until $1982 .^{21}$

There is no doubt that Jeong contributed to the development of violin playing in the country during the pioneering days of Western music. Starting in the 1970s, he devoted more of his attention to orchestral conducting. ${ }^{22}$ One of his significant pupils was Taek Joo Lee (1951-), now professor of violin at Ewha Womans University.

Another important violinist of this generation is Min Jong Park (1918-2006) who was a performer, conductor, and teacher. He contributed to the development of Western music in Korea primarily through solo and chamber music performances. Park first studied the violin with Young Se Lee in Korea and continued his musical studies at Tokyo University of the Arts from 1936 to 1942. After graduation, he became a faculty member at Tokyo University until coming back to Korea in 1943. He taught at Ewha Womans University in 1945 and Seoul National University in 1946 before leaving for Paris in 1952, where he moved to study at the Conservatoire de Paris. After studying for two years, he stayed in Europe for sixteen more years, and played in several orchestras, including as a concertmaster of the Westfalen Symphony Orchestra (WSO). ${ }^{23}$ After returning from his European ventures in 1970, Park shared his musical experiences

\footnotetext{
${ }^{21}$ Han, The Pioneers to be Remembered: The Historical Figures of Western Music in Korea 1, 78.

${ }^{22}$ Park, "Violinist Hee Seok Jeong: His Contribution to the Development of Korean Orchestras," 85.

${ }^{23}$ Han, The Pioneers to be Remembered: The Historical Figures of Western Music in Korea 1, 86-89.
} 
and taught at Kyung Hee University (1970-1972) and Seoul National University (1972-1983). ${ }^{24}$

Park presented many chamber recitals and solo concerts with orchestra along with a steady stream of solo recitals. He was also interested in chamber music. While serving as a professor of violin at Seoul National University, Park organized a string quartet in 1972 (taking the first violin position) and a piano trio in 1977 with cellist Bong Cho Jeon and pianist Jin Woo Jeong (1929-) as faculty chamber ensembles. In addition, in 1984 he organized and conducted the Madri Chamber Ensemble, consisting only of female players, which continues to exist today. ${ }^{25}$

Park never insisted on his own way when dealing with students, but respected each student's character and individual musicianship, and he helped them to bring out their innate musical ideas. ${ }^{26}$ He trained many fine violinists: Jae Hun Lee (1933-), Jong Sook Lee (19372007), Hae Yeop Yang, and Yong-Woo Chun (1959-), who is concertmaster of the KBS Symphony Orchestra and member of the Korean Chamber Orchestra.

\section{The Third Generation of Korean Violinists}

Young Woo Choi (1926-1965), Yong Ku Ahn (1928-), and Jae Hun Lee (1933-) make up the third generation of fine violinists in the country. Among these violinists, Ahn made the most significant achievements in Western music.

Violinist Yong Ku Ahn (1928-) was the first graduate of the Kyungsung School of Music,

\footnotetext{
${ }^{24}$ Han, The Pioneers to be Remembered: The Historical Figures of Western Music in Korea 1, 90.

25 Jin Kyung Noh, "Violinist Min Jong Park’s Contributions to Korean Violin Music," The Monthly Music Magazine Eumagchunchu 164 [April 2009]: 122.

26 Ibid., 124-25.
} 
which was founded by Je Myung Hyun in 1945, and became known as the College of Music at Seoul National University the following year. ${ }^{27}$ There were three professors of violin at the school: Sung Gyo Ahn (a relative of Yong Ku Ahn), Min Jong Park, and Hak Joon Moon; the latter was the teacher of Yong Ku Ahn. During the Korean War (1950-1953), however, Sung Gyo Ahn died, Park went to Paris to continue his studies, and Moon defected to North Korea. Therefore, Yong Ku Ahn became a professor of violin at the school immediately after his graduation in $1953 .^{28}$ After one year, he went to Munich where he studied with Karl Freund (1904-1955), and to Vienna where his teacher was Ricardo Odnoposoff (1914-2004). ${ }^{29}$

Ahn came back to his alma mater to teach violin in 1959, and he became a concertmaster of the National Symphony Orchestra which is known today as the KBS Symphony Orchestra. ${ }^{30}$ He also founded a string chamber ensemble, a string trio, and a string quartet - all of which were named after him - and contributed to the introduction of chamber music to the country. ${ }^{31}$ Although invested in all of these musical activities, he retained a reputation as being primarily a teacher. Many great violinists studied with Ahn: Kyung-Wha Chung (1948-), professor of violin at The Juilliard School; Dong-Suk Kang (1954-), professor of violin at Yonsei

\footnotetext{
27 Seung Rim Noh, "Violinist Young Ku Ahn 1: A Hope that was Found through Music in a Time of Despair," Auditorium 251 [January 2005]: 104.

28 Yong Ku Ahn, As a Bird: Violinist Yong Ku Ahn's 77 Years Life in Music [Gyungki-do, Korea: Hangilart, 2004], 84-85.

29 Seung Rim Noh, "Violinist Young Ku Ahn 2: The Frustration Made Him Turn to Dreams," Auditorium 252 [February 2005]: 89.

30 Ahn, As a Bird: Violinist Yong Ku Ahn's 77 Years Life in Music, 126.

31 Ibid, 130, 133.
} 
University; Young-Uck Kim (1948-), professor of violin at Seoul National University; and Min Kim. Ahn later moved to the USA, becoming a professor of violin at the Peabody Institute (1968-2002).

\section{The Fourth Generation of Korean Violinists}

Many Korean musicians went to Japan to study in the first part of the twentieth century; however, later generations, starting around the middle of the twentieth century, more often chose to go to Europe - especially Germany, France, and Austria - or to the USA. The Korean violinists of the fourth generation made great achievements in developing Western music in the country; they taught many fine violinists and created chamber music ensembles. Jong Sook Lee (1937-2007), Min Kim (1942-), and Nam Yun Kim (1949-) are the most significant violinists and teachers of this generation; Min Kim will be the primary subject of the following chapters.

Violinist Jong Sook Lee (1937-2007) is considered to be the first female violinist in Korea to have received formal Western musical training. She studied with Min Jong Park and Yong Ku Ahn, and stood out for her talent with the violin. Lee entered Seoul National University, where she studied for one semester before leaving for Germany for further studies. After spending time in Munich and Augsburg, where she studied with Rodolf Koecker, she traveled to Bern in Switzerland where she studied with Max Rostal (1905-1991), who was a pupil of Carl Flesch (1873-1944). ${ }^{32}$ She remembered about her teacher Rostal that "he was smart and seldom forgot what he learned, especially regarding music or music education, and so he was very clear

\footnotetext{
32 Seung Eun Lee, "Series of Influential Musicians in Korea 4: Violinist Jong Sook Lee," The Monthly Music Magazine Eumagchunchu 79 [March 2002]: 21-22.
} 
with his teaching." ${ }^{, 33}$ She said that his specialty was fingering: "his fingering showed how music is systematic - the music seems to come out freely through the fingers." 34 Rostal exerted a great influence on her, especially when it came to teaching skills. Lee served as a professor of violin at Ewha Womans University from 1973 to 1983 and at Seoul National University from 1983 to 2003. When she first taught at Ewha, she "never felt nervous about teaching because of the confidence she had gained through Rostal's teachings."35 Many great violinists studied with her, including: Jae Jin Paik (1958-), professor of violin at Dong-Eui University; Jae Kwang Song (1961-), professor of violin at Ewha Womans University; and Won-Kyung Cho (1966-), professor of violin at Seo Kyeong University.

Another remarkable violinist from this generation is Nam Yun Kim (1949-). She studied with Young Woo Choi, who noticed and developed her talent. After graduating from Seoul Arts High School, Nam Yun Kim went to the USA to study with Ivan Galamian (1903-1981) for ten years. ${ }^{36}$ She recalled from her study with him that "Professor Galamian was strict, but also kind and gentle. It was hard to be close to him but I felt he loves his students a lot. However, it was hard to gain recognition from him. He never said 'good' but just 'okay' in response to the playing, and this was his best praise." ${ }^{37}$ Nam Yun Kim said that Galamian influenced not only her

\footnotetext{
33 Jin Soon Ahn, "This Era’s Musician, Violinist Jong Sook Lee," String \& Bow, no. 57 [November 2003]: 36.

34 Lee, "Series of Influential Musicians in Korea 4: Violinist Jong Sook Lee," 22.

35 Ahn, "This Era’s Musician, Violinist Jong Sook Lee," 36.

36 Hye Jung Choi, "Nam Yun Kim: Her Passion as a Violinist and Teacher," String \& Bow, no. 56 [October 2003]: 29-30.

37 Ibid., 30 .
} 
musicianship but also her teaching; one of Galamian's sayings was that "when oxen plow the field, their faces are constrained by a wooden mask so that they can only focus on working silently." ${ }^{38}$ Nam Yun Kim has also said this to her students in order to demonstrate the importance of steady practice. ${ }^{39}$

Nam Yun Kim taught at Kyung Hee University (1977-1983) and Seoul National University (1984-1992) and is now a professor of violin at Korea National University of Arts since 1993; she has gained a reputation as one of great teachers in Korea. ${ }^{40}$ She has served on many juries, including the International Tchaikovsky Competition, the International Paganini Violin Competition in Genova, Italy, and the Queen Elisabeth Competition. Many great violinists studied with Kim: Jun Soo Jeong (1956-), now professor of violin at Kyung Hee University; Kyung Sun Lee (1964-), the sixth-prize winner of the 1994 Tchaikovsky Competition, the bronze medal of the 1993 Queen Elisabeth Competition, and now professor of violin at Seoul National University; Hyuk-Joo Kwun (1985-), the first-prize winner of the 2004 Paganini Moscow International Violin Competition; and Hyun Soo Shin (1987-), the third-prize winner of the 2004 Premio Paganini Competition in Genova, the 2005 Sibelius Violin Competition, and the 2012 Queen Elisabeth Competition.

\footnotetext{
38 Choi, "Nam Yun Kim: Her Passion as a Violinist and Teacher," 30.

39 Ibid.

40 Young Chan Yang, "Monthly Musician: Violinist Nam Yun Kim," Auditorium 152 [October 1996]: 75.
} 
Figure 1: Violin Lineage in Korea

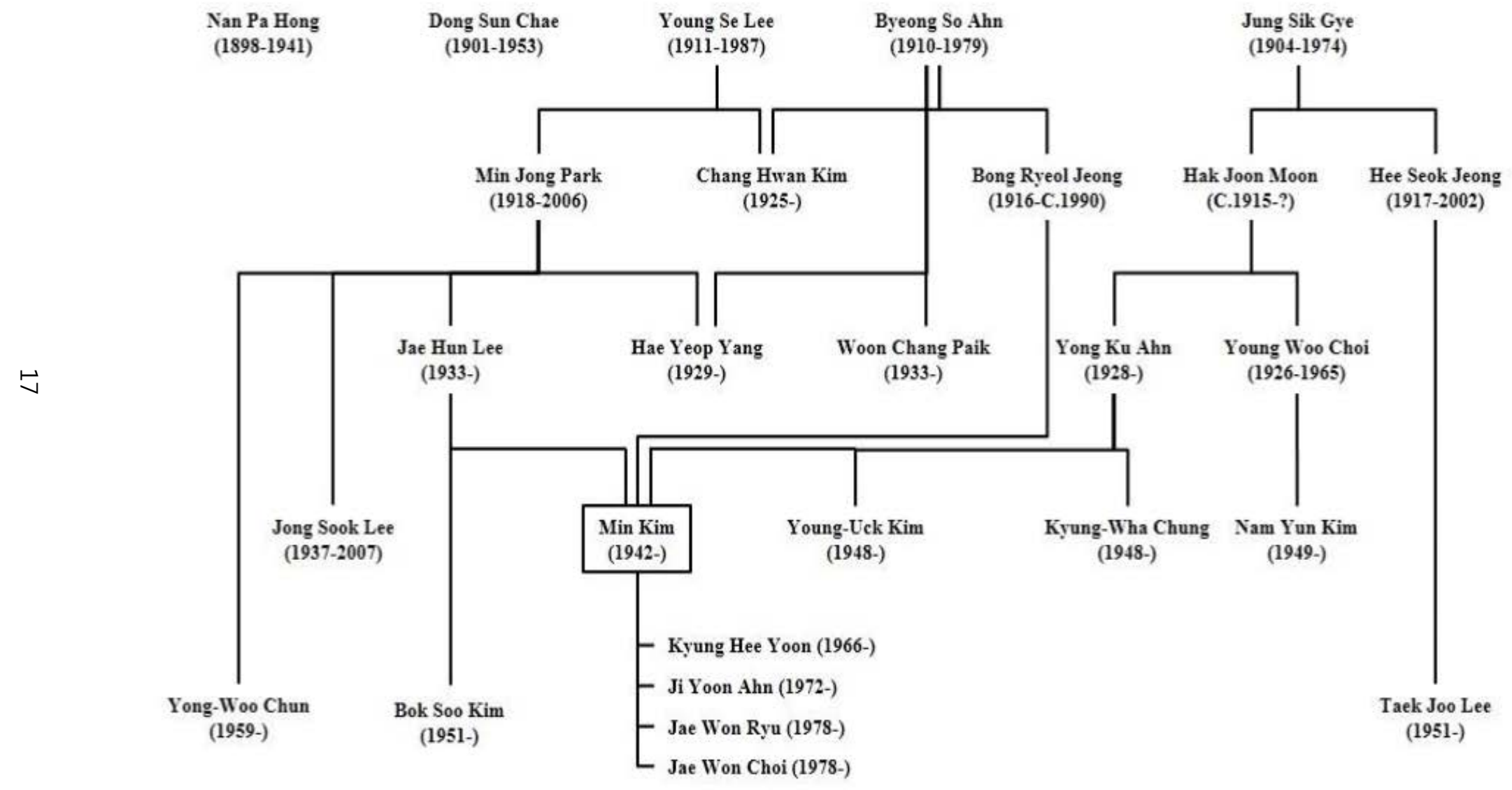




\section{Chapter 3}

\section{Korean Violinist Min Kim}

\section{Background and Musical Education}

\section{Early Life}

Min Kim is one of the most influential advocates of Western music in Korea, with an active career as a violinist, teacher, and especially as a chamber musician. He has made great achievements in the development of performance practice in Western music for strings. Kim has shown an endless passion for music and continues to put great energy into his musical studies to this day.

Kim, who is considered to be the leader in the fourth generation of great violinists in the country, was born on August 10, 1942 in Seoul. He grew up in a musical environment with artistic and musical influences from his parents. His father, Jae In Kim, who was a teacher at Ewha Girl's High School, loved music. He collected recordings of classical music and also played the flute as a hobby. His mother, Jae Soon Lee, studied piano at Ewha Womans College. Even though she did not pursue professional performing activities after graduating from the College, she taught general music at high schools. ${ }^{41}$

Kim's destiny as a musician was seemingly already determined before he was born. His parents prepared a violin for their new baby, buying one that had previously belonged to a

41 Min Kim, interview by author, Buyeo, Korea, August 7, 2012. 
famous Japanese violinist. ${ }^{42}$ Min Kim showed musical aptitude when he was very young; he reacted strongly when listening to Japanese military tunes on the radio and conducted to keep in time with them. ${ }^{43}$ Once they had discovered his talent, his parents decided to support their son's efforts to become a musician. Kim first began studying the piano at the age of six, and a year later he began formal violin lessons with Bong Ryeol Jeong (1916-c.1990). ${ }^{44}$

A few years later, however, the Korean War broke out (June 25, 1950), and his family had to relocate from Seoul to the southern part of the country. At that time he was nine years old, and the situation did not allow him to continue studying the violin. During his refugee life he began to pay more attention to drawing pictures rather than playing the violin; drawing eventually grew into a serious interest for him. ${ }^{45}$

In 1953, South Korea and North Korea agreed to a ceasefire and the War was over. After the War, Kim's family moved back to Seoul, and Kim entered a junior high school. His parents still wanted their son to keep studying the violin, and his father brought him to Jae Hun Lee, who taught violin and conducted the orchestra at Seoul Arts High School at that time (and later became a professor of violin at Yonsei University). Kim, however, continued to devote his attention to art; he once drew pictures during all of his classes at school. He showed significant

\footnotetext{
42 Sung Nam Lee, "The Place where Arts are: Violinist Min Kim," Auditorium 60 [February 1989]: 99.

43 Korea was colonized by the Japanese during this time (1910-1945).

44 Min Kim, interview by author, Buyeo, Korea, August 7, 2012.

45 Ibid.
} 
talent in drawing, and one of his cartoons was once published in the school magazine. ${ }^{46}$

Kim had to decide to pursue either art or music prior to his entrance into Seoul Arts High School. He hoped to study art in more depth, while his parents hoped that he would choose the violin. The eventual decision was strongly influenced by his violin teacher Jae Hun Lee, who recommended that Kim study music at the School. ${ }^{47}$ Kim said, "I did not practice hard at that time, but he kept encouraging me to study the violin, and finally I became attached to him and wanted to follow his advice." ${ }^{48}$ He also said that Lee is one of the most influential teachers in his musical life:

Whenever I was in trouble, Professor Lee would always comfort me and encourage me. When I went to serve in the army for three years, I thought that my musical life would be over. ${ }^{49}$ At that moment, he sent me a letter to encourage me and give me advice. He said that "...look at your life and your musical life in the long term...then you will see that not playing violin for a while will count for nothing in your musical life.",50

\section{Interests in Chamber Music}

Min Kim's early interest in ensemble playing was a rare focus for a violinist in Korea at the time, and there had been only a few chamber ensembles in the period (e.g. Seoul String Quartet in the 1950s). As he said:

\footnotetext{
46 Lee, "The Place where Arts are: Violinist Min Kim," 99.

47 Ibid.

48 Min Kim, interview by author, Buyeo, Korea, August 7, 2012.

49 To serve in the army is compulsory for men in Korea.

50 Min Kim, interview by author, Buyeo, Korea, August 7, 2012.
} 
I have always loved ensemble playing, and began to work on chamber music during my high school years. At Seoul Arts High School, I formed a piano trio with cellist MyungWha Chung and pianist Mi Jae Yoon, and in college I founded the Korean Student Chamber Ensemble. I prefer to make a sound together rather than alone. One day, Chung said, "You loved ensemble playing since you were young and have devoted your life to chamber music," and I just heard this and laughed. ${ }^{51}$

Kim had a pleasant time with the trio for one-and-a-half years; they participated in competitions, including a chamber music competition at Seoul National University, and the trio was asked for many performances. However, the trio could not continue for long because after graduating, Yoon entered Ewha Womans University, Chung went to the USA for her advanced training at The Juilliard School (her siblings violinist Kyung-Wha Chung and pianist and conductor Myung-Whun Chung also trained at the School), and Kim entered Seoul National University, where his teacher was Yong Ku Ahn. ${ }^{52}$

Kim again showed his interest in ensemble music while in college; he organized the Korean Student Chamber Ensemble, which consisted mainly of members who were alumni of Seoul Arts High School, and another chamber group at the University as well. ${ }^{53}$ These efforts naturally allowed him to develop his leadership and musicianship as a chamber musician. Kim was interested not only in chamber ensembles but also in orchestral playing. He began his orchestral activities as a college student, when he played as a section member in the National Symphony Orchestra (now known as the KBS Symphony Orchestra), and after he graduated from the University, he took an associate concertmaster position with the Orchestra. Soon after,

\footnotetext{
51 Tae Hyung Ryu, "Violinist Min Kim: A Gentleman who Loved Ensemble," Auditorium 254 [April 2005$]$ ] 40.

52 Min Kim, interview by author, Buyeo, Korea, August 7, 2012.

53 Gong, "Arts, My Life My Way: Violinist Min Kim," 116.
} 
he left for Germany in order to pursue further studies. ${ }^{54}$ In addition to this, the Korean Chamber Orchestra was founded and he became the concertmaster of the Orchestra in 1965. All of these chamber and orchestral activities helped him become accustomed to playing with other musicians, and to realize, "the thing that I can do is chamber music."

\section{Life in Germany}

In 1969, Min Kim went to Germany in order to pursue his music studies in greater depth as a Deutscher Akademischer Austauschdienst (DAAD, German Academic Exchange Service) student; he was the second student in music who participated in the DAAD from Korea. ${ }^{56}$ Studying in Germany was a turning point for Min Kim, in terms of both his life and his musical career. After graduating from Seoul National University, Kim had first planned to go to the USA to study; however, he could not carry out this plan because of his father's bankruptcy. ${ }^{57}$ Later, he pursued his musical studies abroad, and his time in Germany served to reaffirm his great interest in chamber music. Moreover, it was during his study in Germany that Kim found his lifelong personal and musical companion, as he married pianist Mi Kyung Yoon in 1974; they had one child, a son named Tae Won Kim, who may have been influenced by Kim's artistic talent,

\footnotetext{
54 Gong, "Arts, My Life My Way: Violinist Min Kim," 114.

55 Min Kim, interview by author, Buyeo, Korea, August 7, 2012.

56 Gong, "Arts, My Life My Way: Violinist Min Kim," 114.

57 Min Kim, interview by author, Buyeo, Korea, August 7, 2012.
} 
as he would eventually grow up to study dress design. ${ }^{58}$

While in Germany, Kim studied at the Hamburg University of Music and Theatre, where his teachers were Wilfried Hanke and Thomas Brandis (1935-), who was a pupil of Max Rostal. Kim first became a student of Hanke and recalled that:

When I was studying with him, he was already in his seventies, and since Professor Hanke inherited the characteristics of the traditional German violin school, his teaching was very strict and he never gave praise. He was especially strict with the repertoire of German composers, including Bach and Beethoven; he was also very obstinate musically and did not compromise, always insisting on his own way in his dealings with students. In addition to this, he asked students to be polite during lessons. All of those things made me feel not free, and I seriously thought that 'I may quit studying the violin,' but because of his strict teaching, I was able to make improvements regarding basic issues on which I needed to focus. ${ }^{59}$

After studying for five semesters with Hanke, Kim changed his teacher to Thomas

Brandis. While he was studying with Brandis, the teacher "was in his golden days. Professor Brandis was serving as the concertmaster of the Berlin Philharmonic and pursuing a lot of musical activities at the time. He supported my efforts to have more musical experiences and helped me to find musical activities outside of the school, mostly through chamber ensembles." During this time, Kim had various musical experiences, especially as a chamber and orchestral musician. He served as the concertmaster and soloist of the Köln Chamber Orchestra, N. D. R. Radio Orchestra in Hamburg and Berlin Radio Symphony Orchestra. "Eventually, I kept learning and gaining experience with chamber ensembles in Germany. I really enjoyed these ensemble

\footnotetext{
58 Jung Joon Park, "Violinist Min Kim," Auditorium 178 [December 1998]: 51.

59 Min Kim, interview by author, Buyeo, Korea, August 7, 2012.

60 Ibid.
} 
activities, and I realized once more that the thing that I can do is chamber music," Kim said. ${ }^{61}$

\section{$\underline{\text { Teaching at Seoul National University }}$}

In 1979, Min Kim returned from Germany to serve as concertmaster of the National Symphony Orchestra, which is now known as the KBS Symphony Orchestra. Here he began to share his musical experiences with the next generation of Korean musicians. He returned to his alma mater to teach violin and remained in this position for twenty-seven years.

Kim said, "the students whom I teach are my mirror," and he claimed that he also learned through teaching them ${ }^{62}$ He respects each student's talent and personality: "it is important to figure out each student's characteristics in order to teach them effectively," he said, and he noted that he tried to teach according to each one's level because "everyone has a different level of talent, so I need to be prepared to give them different suggestions; some need very systematic training for solidifying their technical issues, while some do not but need

musical training."63 He also said that "a lot of patience and effort are required in teaching."64

One of Kim's pieces of advice to students was that "the most effective way to practice is to be faithful to basic things," and he asked them to practice basics first (e.g. scales and etudes)

\footnotetext{
61 Min Kim, interview by author, Buyeo, Korea, August 7, 2012.

62 Ibid.

63 Ibid.

64 Hye Jung Choi, "Violinist Min Kim and Young Violinists," String \& Bow, no. 56 [October 2003]: 69.
} 
before playing a piece. ${ }^{65} \mathrm{Ji}$ Yoon Ahn (1972-), member of the violin faculty at Kyung Hee University and Sejong University, who began to study with Min Kim in her second year of junior high school, said, "Professor Kim spent much of the lesson time on scales and etudes, and he never skipped this step...I could not fully internalize all of his comments at that time, but now I know what he meant, and keep it in mind when I am teaching." 66

Kim also recommended that, when students learn the music, they "do not just focus on playing the violin, but study the composers as well, including the historical and cultural background of the composer's country, in order to better understand the music."67 Jae Won Choi (1978-), member of the violin faculty at Seoul Arts High School and Yewon School, who studied with Kim for four years at Seoul National University, remembered that:

I studied German composers' sonatas in greater depth, rather than studying brilliant concertos. Bach and Beethoven, for example...he told me that "there are things that you will not understand naturally because you are not German. Therefore you have to learn those things through study." So I had to study not only the composers themselves but also the situation of their home countries during their lives. In comparison, to read the music score precisely seemed very basic! ${ }^{68}$

Min Kim also emphasized to his students the importance of being professional and controlling themselves while on the stage. His student Jae Won Ryu (1978-), adjunct professor of violin at Seo Kyeong University, who studied with him (1996-2000) at Seoul National University, recalled that "Professor Kim always told me to be very flexible in my performing, because the

\footnotetext{
65 Choi, "Violinist Min Kim and Young Violinists," 70.

66 Ji Yoon Ahn, interview by author, Buyeo, Korea, August 7, 2012.

67 Hee Won Jeong, "Violinist Min Kim: Always a Young Musician," String \& Bow, no. 98 [April 2007]: 27.

68 Jae Won Choi, interview by author, Buyeo, Korea, August 7, 2012.
} 
situation can always change during a lesson and on the stage during a concert as well. He really emphasized flexibility."69 Another pupil, Kyung Hee Yoon (1966-), professor of violin at Sejong University, who studied with Kim for six years, remembered that:

Professor Kim stressed that we should let the music flow, and he hated student-like and machine-like playing. He asked students to be professional on the stage...moreover, he emphasized playing the music with our own color and style. For instance, even though Brahms composed the piece, I am now the one who is playing it, and so I have to show my understanding of Brahms with my own color and style. In other words, Professor Kim helped me to understand music well and to bring out the ideas...not just playing the violin from rote physical memory. ${ }^{70}$

Kim respected students' ideas and styles of violin playing rather than insisting that his

own way be followed. Kyung Hee Yoon said:

He taught me musically in our lessons. He let me feel free during lessons and said that I could play whatever I wanted. Professor Kim, however, did give me a guideline and asked me to work within it. For instance, when I was learning Saint-Saëns Concerto with him, he said, "the music is not in that mood. Where is he from? He is French, and so what would be the difference between French and German music in general? German music is more serious and grave rather than humorous. How about French music? It is more graceful, elegant and a little bit lighter. But your Saint-Saëns is too serious and more German in taste." He commented on my playing with this kind of insight and did not give specific demonstrations about how I could make it sound more French - e.g. use the bow like this, give an accent here and there, do this and that for making French style - and let me find out by myself. It took time for a full understanding to set in, but once I realized what he meant, then the idea would become absolutely mine. ${ }^{71}$

Kim said, "there is no shortcut in music. If you love music, just enjoy it and try to look farther into the future. You cannot make real music if you keep comparing yourself with those who have acquired worldwide reputations through international competitions or are in the

\footnotetext{
69 Jae Won Ryu, interview by author, Buyeo, Korea, August 7, 2012.

70 Kyung Hee Yoon, interview by author, Buyeo, Korea, August 7, 2012.

71 Ibid.
} 
spotlight, and you become hasty and disappointed with your situation. It is most important to keep giving constant effort and maintaining your affection for music."72

\section{As a Dean of the College of Music at Seoul National University}

During his tenure as a professor of violin at Seoul National University, Kim was also involved in many musical activities including performances as a violinist, a concertmaster of the KBS Symphony Orchestra, and a leader and director of the Korean Chamber Orchestra. He served as dean of the College of Music at the University from 1999 to 2005 and showed great enthusiasm in the performance of his duties.

During this time, the DMA (Doctor of Musical Arts) degree was created at the College of Music in order to allow students to pursue studies at a more advanced level; the College of the University had graduated doctoral students as Ph.D students until creating the DMA degree. ${ }^{73}$ Furthermore, he organized an exchange project with Mannheim University of Music and Performing Arts to make a united orchestra - presenting concerts in Germany, Korea, and the USA - in order to give students a greater variety of experiences. ${ }^{74}$ His efforts helped to improve students' lives at the school. Jae Won Choi said, "there is a library at the University, but the reference books are not extensive enough to take care of our needs. In addition to this, even though there are recordings at the library, students are not allowed to borrow them. Professor

\footnotetext{
72 Kyung Hwa Jeong, "Min Kim Violin Recital," String \& Bow, no. 62 [April 2004]: 44.

73 Ryu, "Violinist Min Kim: A Gentleman who Loved Ensemble," 44.

74 Seung Eun Lee, "Series of Influential Musicians in Korea II: Violinist Min Kim," The Monthly Music Magazine Eumagchunchu 86 [October 2002]: 29.
} 
Kim actually helped to change things for students' greater convenience. ${ }^{, 75}$ Kim believes that "the school exists for and belongs to the students, and the faculty and members must give support to them.".76

Kim said he "feels worthy when my students make remarkable achievements in the field of music and contribute to society, and I also feel obliged to give greater effort to my teaching.,"77

75 Jae Won Choi, interview by author, Buyeo, Korea, August 7, 2012.

76 Ryu, "Violinist Min Kim: A Gentleman who Loved Ensemble," 44.

77 Song Hee Han, "Violinist Min Kim," The Monthly Music Magazine Eumagchunchu 141 [May 2007]: 44. 


\section{Chapter 4}

\section{Kim as a Director and Leader of the Korean Chamber Orchestra}

\section{The Korean Chamber Orchestra}

Many Korean musicians have acquired worldwide reputations as fine musicians, including pianist and conductor Myung-Whun Chung, violinists Kyung-Wha Chung and Sarah Chang. Despite the individual successes of Korean musicians, there have been few Korean ensembles that have gained such international renown. To this day, many chamber ensemble groups have been created only to disappear before long. The forty-seven-year history of the Korean Chamber Orchestra is a remarkable exception in the hundred-year history of Western music in Korea.

The Korean Chamber Orchestra is Korea's oldest chamber ensemble and is considered to be the one of best ensembles in the country. ${ }^{78}$ It was founded in 1965 by cellist Bong Cho Jeon (1919-2002), who at the time was a professor of cello at Seoul National University. Jeon made a trip to Europe as a Korean representative to the 8th International Music Council in 1960. During his visit, he was very impressed by the chamber ensemble activities in Europe, which mainly focused on Baroque music; this motivated him to pursue his own chamber ensemble activities. When he returned to Korea, he brought with him many music scores for chamber ensemble, and

\footnotetext{
78 The Korean Chamber Orchestra's name in Korea is the Seoul Baroque Chamber Ensemble; the group, however, uses the name of Korean Chamber Orchestra in English because the name "Baroque" gives a misleading impression about its repertoire focus. The Orchestra presents the music of various periods, with no particular emphasis on Baroque music.
} 
this was how he was able to create a chamber ensemble course at the University. ${ }^{79}$

In 1965, Jeon organized the members of the Korean Chamber Orchestra based on completion of the ensemble course; Min Kim was among the most impressive of the students, and became the first concertmaster of the ensemble. ${ }^{80}$ The Orchestra, however, stopped giving concerts in 1975; Jeon became a dean of the College of Music at the University in the same year, and young members of the Orchestra, including Min Kim, went to study abroad during these ten years. ${ }^{81}$ Until 1975, Jeon managed everything for the Orchestra while also serving as the dean of the College at the University. To lead the ensemble without any sponsor or supporters must have been challenging. "It was the same situation as today, maybe worse. It must not have been easy for Professor Jeon to manage all the things for the Orchestra as well as taking on the responsibilities of the dean of the music department. There came a point where he could not lead the group anymore because of all the demands on his time. This is the reason why the Orchestra was stopped. This is what he told me," Kim said. ${ }^{82}$

In 1979, Min Kim came back from his studies in Germany and learned that the Korean Chamber Orchestra had disbanded. Since he was greatly interested in chamber ensemble performance and had had various musical experiences related to chamber music, he hoped that he could also create a chamber ensemble group. He realized that "this was the thing that I should

\footnotetext{
79 Sang Woo Han, "The 40th Anniversary, the Korean Chamber Orchestra," String \& Bow, no. 76 [June 2005$]: 23$.

80 Kim, "The 45th Anniversary, the Korean Chamber Orchestra," 21.

81 Hye Jung Choi, "The 40th Anniversary, the Korean Chamber Orchestra and its Music Director and Leader Min Kim," String \& Bow, no. 76 [June 2005]: 26.

82 Min Kim, interview by author, Buyeo, Korea, August 7, 2012.
} 
do. ${ }^{83}$ He went to see Bong Cho Jeon and asked if he could re-organize the Orchestra so that its legacy could be continued. Jeon was willing to support Kim's decision and gave him all the materials relating to the Orchestra; Kim took over as the leader of the group and has been involved with it as a director and leader until the present. The only difference between Jeon and Kim was that Jeon led the group as a conductor, while Kim led it without a conductor through his role as concertmaster. He recruited the players mainly from the seniors of Seoul National University and the National Symphony Orchestra, and the Orchestra gave a second debut concert in $1980 .^{84}$

\section{Kim said:}

At that time, there was no chamber group which had a significant history and tradition in the country; therefore, I wanted the Korean Chamber Orchestra's history to be continued under its original name. Now, however, I think that it might have been okay if I had changed the Orchestra's name and began an entirely new group at that time, because I have been concerned about the name "Baroque." Since the Orchestra's name is Seoul Baroque Chamber Ensemble [in Korea], people assume that we only play Baroque music. Therefore, we began to use the name Korean Chamber Orchestra for concerts in other countries. This is why we use double names for the group. I think we need to unify the group's name into one, and we keep discussing the question of when we are going to change it - either next year or in its fiftieth anniversary year it will be changed to Korean Chamber Orchestra. I wanted to inherit the tradition of Seoul Baroque Chamber Ensemble, but now it has caused something of a dilemma for me because of the name. ${ }^{85}$

Kim is a person who considers history to be an important part of any endeavor; he has kept all materials and records regarding the Korean Chamber Orchestra for the sake of those people who want to know about the Orchestra in the future. He has felt keenly the lack of past

\footnotetext{
83 Min Kim, interview by author, Buyeo, Korea, August 7, 2012.

84 Ryu, "Violinist Min Kim: A Gentleman who Loved Ensemble," 40.

85 Min Kim, interview by author, Buyeo, Korea, August 7, 2012.
} 
materials - e.g. music programs, recordings, and photos - in the music field of the country; it was the same situation when he re-organized the Orchestra in $1979 .{ }^{86}$ He said, "From 1980 to 1994, I devoted my whole life to the Korean Chamber Orchestra and managed everything alone; making a plan, designing the posters, casting, and so on. Even when I earned some money from other activities, I spent all of it on the Orchestra." ${ }^{, 87}$ To lead the group without regular support must have been difficult in the early days; however, Kim tried several approaches for the development of the group based on his experiences from ensembles in Germany.

Kim's strategies for increasing audience turnout and increasing general awareness of the Korean Chamber Orchestra were: (1) setting up subscription concerts, (2) presenting concerts in other countries, and (3) producing recordings. ${ }^{88}$ He first established subscription concerts through a membership system for the Orchestra. The subscription concert is "[originally] a concert whose costs are met by subscribers, especially one of a series of such concerts; [later more generally] a concert, typically of classical music, to which admission is obtainable by paying a subscription in advance." 89 The first task of Kim and the Orchestra was to acclimate people to the concept of ensemble playing so that they would grow to like chamber music while the musicians had to keep studying the repertoire and working to improve the quality of their

\footnotetext{
86 Lee, "Series of Influential Musicians in Korea II: Violinist Min Kim," 31.

87 Ryu, "Violinist Min Kim: A Gentleman who Loved Ensemble," 42.

88 Ibid.

89 Oxford English Dictionary, s.v. "Subscription Concert," http://www.oed.com/view/Entry/192959\#eid235100163 [accessed September 27, 2012].
} 
playing. ${ }^{90}$ The audiences of the Korean Chamber Orchestra have constantly increased throughout the years and the orchestra has many fans and supporters today. The Korean Chamber Orchestra now has more than twelve hundred regular audience members. This is the fruit of the devoted efforts of Kim and the other members. "The most important element of chamber ensemble playing is being unified; inside of this harmony, there is each member's playing, and it eventually makes music...to find the proper sound and the exact interpretation of the music is endless work. The process is hard but I think that this is chamber music's appeal," Kim said. ${ }^{91}$

Another effort made by the Korean Chamber Orchestra was to introduce the Orchestra to other countries. The first concerts in foreign countries were in Tokyo, Washington DC, and New York City in 1987. The success of these first three concerts gave Kim and the other members the confidence that they could succeed internationally. ${ }^{92}$ The Korean Chamber Orchestra began to perform on the international stage in earnest in 1995, including a nine-city tour in the United States and Canada in 1995 - arranged by Columbia Artists Management Inc.. Later important concerts have included a Salzburg debut in 1999, the UNESCO Concert for Peace in Paris in 1999, and the UN Staff Day Concert at the UN General Assembly Hall as a UN Chamber Orchestra in 2000. ${ }^{93}$ "The next task of the Korean Chamber Orchestra as we continue our improvement is to be recognized anywhere in the world. Now we have many chamber groups in

\footnotetext{
90 Han, "Violinist Min Kim," 42.

91 Ibid., 42-43.

92 Ryu, "Violinist Min Kim: A Gentleman who Loved Ensemble," 42.

93 Korean Chamber Orchestra, "Profile," http://www.kco.or.kr/01-01.htm [accessed September 20, 2012].
} 
the country and our repertoire has almost reached the limit; therefore, more efforts and studies are needed in order to further broaden our horizons, including playing works by living composers," Kim said. ${ }^{94}$

The Korean Chamber Orchestra has actually tried to present a variety of repertoire at each performance. For instance, consider the two performances at the Naantali Music Festival in Finland, 2010: the first concert presented the Cello Concerto - written in 2010 and dedicated to its performer at this concert, Arto Noras (1942-) - by Korean composer Jae Joon Ryu (1970-), the String Quartet No. 3, Some Aspects of Peltoniemi Hintrik's Funeral March, Op. 19 (1969) by Finnish composer Aulis Sallinen (1935-), and the Tchaikovsky Serenade; the program of the second concert included Respighi's Antiche Danze ed Arie, Korean composer Isang Yun's Tapis pour cordes, Mendelssohn's Concert Piece No. 2 for Clarinet, Cello, and Strings, and Beethoven's Rasumovsky Quartet in C Major, Op. 59 No. 3, arranged for string orchestra. ${ }^{95}$

Music festivals offered a great opportunity for the Korean Chamber Orchestra to introduce itself. Due to the nature of festivals, tickets are sold by concert series. For instance, "in the case of Rheingau Musik Festival, the audiences buy tickets for the entire concert series. They come and listen to not only the concerts of the Berlin Philharmonic Orchestra and the New York Philharmonic Orchestra but also the Korean Chamber Orchestra, which is programmed in the series. The group has to earn a fine response to the concert so that we can be invited again to the

\footnotetext{
94 Han, "Violinist Min Kim," 43.

95 Won-Kyung Cho, "The Korean Chamber Orchestra 2010 European Trip," String \& Bow, no. 138 [August 2010 ]: 49.
} 
festival and to other festivals as well," Kim said. ${ }^{96}$ The Orchestra began to present their concerts at festivals, and is now invited to many festivals including Naantali Music Festival in Finland (2005, 2007, 2010), Rheingau Festival in Germany (2005, 2007, 2009), and Mozart Festival in Estonia (2006). ${ }^{97}$ Since its first concerts in Japan and the USA in 1987, the group has presented more than a hundred concerts all over the world.

Another effort by the Korean Chamber Orchestra to increase awareness of the group is through the production of recordings. "The confidence we gained from the first concert in a foreign country [in 1987] led us to decide to produce a recording," Kim said. ${ }^{98}$ The processes of recording were "such an intensive training that the Orchestra reached an international level. Since all of the members have their own musical activities [in addition to the Korean Chamber Orchestra], scheduling all members together was a challenge. Kim gathered more members and adapted a rotation system for better quality of performing." 99 The Korean Chamber Orchestra has made fourteen recordings to date; its first recording was released in 1988 and the most recent recording in 2005 covering a wide variety of repertoire from Baroque to contemporary. ${ }^{100}$ Through all these endeavors, the Korean Chamber Orchestra has continued to develop and to improve its quality. To rise to the level it is at today required not only Kim's devotion to

\footnotetext{
96 Yong Wan Park, "To Sir with Love: Violinist Min Kim and Kyung Hee Yoon," Auditorium 278 [April 2007 ]: 84.

97 Korean Chamber Orchestra, "Profile," http://www.kco.or.kr/01-01.htm [accessed September 20, 2012].

98 Park, "To Sir with Love: Violinist Min Kim and Kyung Hee Yoon," 84.

99 Ryu, "Violinist Min Kim: A Gentleman who Loved Ensemble," 42.

100 Korean Chamber Orchestra, "CD Discography," http://www.kco.or.kr/03-03.htm [accessed September 20, 2012].
} 
the Orchestra but that of all the other members as well. Kim said that the audition process was not really necessary, as:

Ensemble is playing together, and so personality is an important element in assuring unification. Also it requires the ability to play the instrument at some level. I cannot say with certainty which one is more important for being a good chamber musician. It would be a problem if someone was a very nice person but was not good at playing his/her instrument. On the other hand, if someone's playing is great but he or she cannot listen to others' sound or consider other opinions, this would also be a problem. Therefore, I consider both. First of all, I look at their ability with the instrument, but they do not need to be virtuosic performers. The ability criterion means just qualifying at some level; the qualifying means some degrees from school either in the country or other countries. It means passing an exam from a music institution. I consider that much a qualification for ability. I do not think an audition is necessary in order to choose members...then, personality is considered to be unified. Since a chamber ensemble cannot be brought together in a short time, keeping in tune with others is important. ${ }^{101}$

Once they have become members of the Korean Chamber Orchestra, many musicians remain a part of it for a long time; some of them have played in the Orchestra for more than twenty years (e.g. Yong-Woo Chun and Kyung Hee Yoon). The Orchestra members are seldom changed, and this leads to "a guarantee that their playing will be coherent." 102 Therefore, they have a strong family-like fellowship and it allows them to be unified with each other's sound. German violinist and conductor Robert Koenig, who has kept a friendship with Kim since they met at Bayreuth Festival Orchestra in 1977, said that the Korean Chamber Orchestra's "family character" is the specialty of the group, and he thinks that their fine playing is because they know each other so well. ${ }^{103}$ In addition to this, most of the members are from the same University;

101 Min Kim, interview by author, Buyeo, Korea, August 7, 2012.

102 Tae Hyung Ryu, "The 35th Anniversary of the Korean Chamber Orchestra and its Leader Min Kim," Auditorium 200 [October 2000]: 118.

103 Robert Koenig, interview by author, Buyeo, Korea, August 7, 2012. 
some of the violinists are Kim's students. "It is much easier [to play together] when the people come from the same school and the same teacher," Koenig said. ${ }^{104}$

Jae Won Choi, who has been a member of the Korean Chamber Orchestra since 2011, felt a strong solidarity among members and said:

We played the Tchaikovsky Serenade for the opening concert of the Korean Chamber Orchestra music camp this year [2012]; of course, other members must have played the piece a lot of times. Since they have worked alongside each other at the Orchestra for a long time, they did not really need to discuss how to make the music, but just listen to each other sensitively, and it was already great music. They must have spent a lot of their time studying and giving concerts together, but they are still training. I feel that since I have been a member of the group, I need to put in a lot of effort at becoming like them, not just following them. ${ }^{105}$

Kim said that to be a good chamber musician, "performers should make a variety of tone, and they have to use these tones in the proper place; tone should be different in a solo, duet, and so on. They need to train for this variety...for instance, the piano in solo, in trio, and tutti must be distinguished and they have to know how to make it differently. In other words, they can control their sound and tone, and adjust them depending on the music."106

Kim explained that the hardest part of leading the Korean Chamber Orchestra is finding "the balance of each part including musical balance and sound, and the flowing of the music overall...since I am not a conductor it is difficult to lead the Orchestra as a violinist. Therefore, the most difficult thing is the general issue of balance...so I keep studying these questions in

\footnotetext{
104 Robert Koenig, interview by author, Buyeo, Korea, August 7, 2012.

105 Jae Won Choi, interview by author, Buyeo, Korea, August 7, 2012.

106 Min Kim, interview by author, Buyeo, Korea, August 7, 2012.
} 
order to make a better sound and have a better balance." 107

The Korean Chamber Orchestra will celebrate its fiftieth anniversary in 2015. When it was first organized by Jeon in 1965, even professional musicians lacked a true concept of chamber ensemble repertoire, so the Orchestra had to focus on introducing ensemble music in order to build up its audience. On this point, the Korean Chamber Orchestra has made quite an achievement in that people have learned to enjoy both chamber orchestra and smaller chamber ensemble music, and there is no doubt that it is much easier to form a chamber ensemble thanks to Kim's contributions. "To expand the audience in the country was the group's task at first; and for decades, we have accomplished this to some degree. Now, I hope that the Korean Chamber Orchestra helps ensure that chamber ensemble playing can be developed to the same degree as other [individual] types of music," Kim said. ${ }^{108}$ Ensemble performance in Korea is not yet at the level of individual performance (e.g. piano and violin) and he said that musicians also need to realize the importance of teaching ensemble music to students alongside their individual work; musicians should not distinguish between individual music and chamber music but consider music as one. "There are 144 music institutions in Korea which can give a college education; however, only $20-30 \%$ of the schools ask students to take a chamber class as a required course. I hope that musicians' thinking regarding chamber music can be improved. I consider this as the next task for me and the group, for the sake of present and future musicians," Kim said. ${ }^{109}$

\footnotetext{
107 Min Kim, interview by author, Buyeo, Korea, August 7, 2012.

108 Ibid.

109 Ibid.
} 
The Korean Chamber Orchestra became an incorporated association in 2003, and has retained Krzysztof Penderecki, a Polish composer and conductor, and Young-Uck Kim, a professor of violin at Seoul National University, as its artistic advisors since 2008. It now has more than seventy members - they are rotated for concerts - and keeps moving forward. There is no doubt that the person who gave the greatest contribution to the Korean Chamber Orchestra is violinist and leader Min Kim.

Ji Yoon Ahn does not think that Kim has led the Korean Chamber Orchestra for such a long time for the sake of personal achievement or a desire for honor, but because he hoped to establish a strong foundation for classical music in Korea. She also said that:

It must be difficult for chamber music to become rooted in the musical culture of Korea, which focuses mainly on soloists. The Korean Chamber Orchestra, however, became one of the most successful chamber orchestras in the country. The Orchestra has provided a good example of the possibility that musicians can continue to perform at a high level in this country even though they are not soloists or members of a large orchestra. This will serve to broaden the classical-music ecosystem of the country. The members of the Korean Chamber Orchestra understand that Professor Min Kim puts a great deal of effort into making this ecosystem based on variety, while Professor Nam Yun Kim devotes her identity as a violinist to the teaching and training of soloists. ${ }^{110}$

Jae Won Ryu said, "Professor Kim is a leader in every sense of the word. He is the

person who represents the vitality and nobility of the group, and our own color. Moreover, he has a far-sighted approach to the group's affairs. Therefore, he is a veritable leader." ${ }^{111}$ Kyung Hee Yoon, who has been a Korean Chamber Orchestra member since 1986, said, "he is over seventy years old now and there are various ages in the Orchestra from mid-20s to mid-50s. However, we

\footnotetext{
110 Ji Yoon Ahn, e-mail message to author, October 28, 2012.

111 Jae Won Ryu, interview by author, Buyeo, Korea, August 7, 2012.
} 
cannot match his passion for music and also his leadership. I mean leadership that includes taking the initiative to improve, having a far-sighted approach, and handling all of the administrative elements; a leader of an orchestra cannot be a good leader if he/she knows only about music in the Korean music system. There is no one yet to take on the role as a music director, leader, and handler of administrative matters at the Korean Chamber Orchestra - all at the same time - as Professor Kim has done."112

\section{Other Musical Activities of the Korean Chamber Orchestra}

Min Kim retired from Seoul National University in 2007 after serving twenty-seven years as a professor of violin; however, he has continued his efforts to develop young musicians with the Korean Chamber Orchestra Music Academy since 2005, being aware of the importance of solidifying and developing students' basic skills from a young age. It was for this reason that the Orchestra created the Music Academy in 2005, where talented young musicians are discovered and educated. The Academy offers not only a program for all ages (from young children to high school students) focused on both basic lessons and performance practice, but also a program for non-majoring students. ${ }^{113}$ The Korean Chamber Orchestra also holds a music camp every summer; the program of the camp is organized to focus on private lessons, chamber music coachings, and performance for participants. In addition to this, there is a competition including chamber music as a category - held by the Orchestra every year in order to discover

\footnotetext{
112 Kyung Hee Yoon, interview by author, Buyeo, Korea, August 7, 2012.

113 Hee Won Jeong, "Violinist Min Kim: Always a Young Musician," String \& Bow, no. 98 [April 2007]: 27.
} 
future musicians.

In 2010, the office of the Korean Chamber Orchestra moved to the Korean Chamber Orchestra Hall at Seocho-dong in Seoul, near where the Seoul Arts Center is located; the place is considered to be a culture and arts area with many music halls and string [repair] shops. ${ }^{114}$ "Whenever I was suffering with music, there seemed to be a chance to overcome the difficulty. I would like to say to budding musicians that there will always be a chance if they do their best," Kim said. ${ }^{115}$ He was actually in a difficult situation several times. For instance, the Korean War began not long after he started formal violin lessons, and his father went bankrupt right before Kim decided to go to the USA to study. However, he tried to do his best no matter what situation he was in, and he did not miss the chance. When asked how he could lead the Korean Chamber Orchestra for such a long time, Kim answered, "of course it was not easy, but I did not feel it is difficult and tiring because I like the work so much...I could do my best for the work because I like it [chamber ensemble], and then many chances presented themselves. Now, we have a place where the Korean Chamber Orchestra can reside and we can expand our vision." ${ }^{\prime 16}$ He wants the Korean Chamber Orchestra Hall to become "a mecca of chamber music" in the country. ${ }^{117}$

\footnotetext{
114 Ye In Park, "A Director of the Korean Chamber Orchestra, Min Kim," The Monthly Music Magazine Eumagchunchu 182 [October 2010]: 43.

115 Ji Yeon Kook, "Violinist Min Kim: Dream a Mecca of Chamber Hall," String \& Bow, no. 140 [October 2010]: 55.

116 Ibid.

117 Ibid.
} 


\section{$\underline{\text { As a Chamber Musician }}$}

As a violinist, Min Kim spent most of his professional life working as a chamber music musician and orchestra player. He participated in the Bayreuth Festival and served as a member of the Bayreuth Festival Orchestra from 1977 to 2007; he recently stopped participating in the Festival because he reached the Orchestra's mandatory retirement age of $65 .{ }^{118}$ He received "the appreciation plaque from Wolfgang Wagner, a director of the Bayreuth Festival, for his twenty consecutive years of participation in the Festival (2002)."119 He helped to organize the Wagner society in Korea in 1993. He was also the concertmaster of the KBS Symphony Orchestra, considered to be one of the greatest orchestras in the country, for thirteen years. In addition to this, he took a position as music director of Korean Symphony Orchestra.

Kim has made a specialty of playing contemporary music and often featured new works on both his solo recitals and chamber music concerts. He realizes the importance of introducing Korean composers' music as well. Since he became acquainted with Isang Yun during his studies in Germany, he has developed a fine understanding of Yun's music. ${ }^{120}$ Kim organized the Isang Yun Ensemble Seoul in 2007, and he has tried to introduce more of Yun's music, often

\footnotetext{
118 Robert Koenig, interview by author, Buyeo, Korea, August 7, 2012.

119 Korean Chamber Orchestra, "Music Director," http://www.kco.or.kr/eng/e01-02.htm [accessed September 22, 2012].
}

120 Korean-born composer Isang Yun (1917-1995), considered to be one of greatest composers in Korea, established his musical career mainly in Europe (especially Germany). Yun visited North Korea in 1963 during his period of study in Berlin; later he became enmeshed in political issues, and was kidnapped by the South Korean Government and sentenced to life in 1967. However, he was released and returned to Berlin in 1969 because of a worldwide petition with approximately two hundred artist's signatures including Igor Stravinsky, Herbert von Karajan, Heinz Holliger, and Karlheinz Stockhausen; he obtained German citizenship in 1971, but could not return to South Korea for the rest of his life. 
programming concerts consisting mostly of his pieces. There already exist an Isang Yun Ensemble Berlin in Germany and Isang Yun Orchestra in Pyongyang, North Korea. Now there is an Ensemble in South Korea, and Kim is currently the music director of the Ensemble, a position he has held since 2007.

Kim's constant efforts and challenges helped to further the development of chamber music in the country, and he said, "A good ensemble cannot be unified even though each member is good at playing. They can be unified only when they try to listen to each other to match the balance, and once they fully understand the composer and piece, they can make it...Artists should keep their efforts focused on presenting music with more depth as time goes by. We are the people who keep moving forward." ${ }^{121}$

121 Ji Yeon Kook, "Min Kim and Dae Wook Lee, Beethoven Violin Sonata Recital," String \& Bow, no. 145 [March 2011]: 29. 


\section{Chapter 5}

\section{Conclusion}

Min Kim, professor emeritus at Seoul National University, music director of Isang Yun Ensemble Seoul, and leader and director of the Korean Chamber Orchestra, recently celebrated his seventieth birthday, yet he still remains busy with musical activities. He has presented a solo recital every three or four years; his most recent recital was in 2011 with pianist Dae Wook Lee (1947-), professor of piano at Hanyang University, and it featured the complete sonatas of Beethoven over the course of three days. "People express concern about me when they hear that I am going to play the complete sonatas of Beethoven. They seem to think that it is a difficult challenge at my age. It is tough for a performer to play a whole cycle, but I have long thought that it must be a worthy challenge for a musician...I have decided to perform them when the chance was given because the performance of the complete sonatas requires a lot of effort and strength," Kim said. ${ }^{122}$ This shows Kim's endless passion for and study of music, and his attitude provides a wonderful example as an inspiration for the younger generations.

Many have spoken of their admiration and respect for the constant energy that he puts into his musical studies. Ji Yoon Ahn especially respects Kim's long-standing concentration on music, and also his enduring affection for it. She said, "I sometimes need suggestions on programs for my solo recitals and ask for Professor Kim's advice on this. He always recommends pieces - seldom played in the country - that are a great fit not only for me but also for the concept of the recital. His knowledge of this large repertoire is a sign that he still devotes

122 Kook, "Min Kim and Dae Wook Lee, Beethoven Violin Sonata Recital," 26. 
effort to studying new music, and this effort must be inspired by his love for music."123

Ahn also said that a strong influence from Kim is found in her experiences with chamber music: "I did not have many experiences with chamber ensemble playing. After I became a member of the Korean Chamber Orchestra, I developed an interest in chamber music. I actually felt the difficulty of ensemble in terms of playing together; however, now I know how to blend, to get a sense of what the others are doing, and to create a sound."124

Kyung Hee Yoon also testifies to Kim's lasting significance. Yoon studied with Kim for six years; however, during this time, she already became his colleague before graduating from Seoul National University because of her membership in the KBS Symphony Orchestra and Korean Chamber Orchestra. Therefore, Kim was a very influential teacher and mentor for her. She said he affected not only her musical life but other aspects as well, including how she approached thinking, treating things and people, and values. Regarding music, she respects his endless passion: "I really respect and want to emulate his passion for music, and especially for chamber music. The surprising thing is that his music keeps developing even though he recently turned seventy. He does not regress, but keeps developing musically... he is my role model in both music and life.",125

Kim's former student Jae Won Ryu also praises Kim, saying, “before I met Professor Kim, I was very stubborn. I only knew myself and did not want to listen to other people. That

\footnotetext{
123 Ji Yoon Ahn, e-mail message to author, October 28, 2012.

124 Ji Yoon Ahn, interview by author, Buyeo, Korea, August 7, 2012.

125 Kyung Hee Yoon, interview by author, Buyeo, Korea, August 7, 2012.
} 
was a big problem, so I learned [from him] how to live and play with other musicians, and one of the most important things that I learned is to control the situation on the stage, to control myself whether in a small chamber group, a big chamber group, etc..."126

These pupils were greatly influenced by their teacher, Min Kim, especially in chamber music, and they deeply admired him. In other words, Kim has also put forward an important example to be followed by his pupils and the next generations of musicians in Korea.

Kim has also communicated a significant vision for music education. Western music in Korea today has been developed and improved thanks to the environment of the music education system, and it has become possible to train fine musicians in the country. Many young musicians, however, still choose to study in other countries in order to add greater depth to their musicianship. Kim's thoughts on this matter are that "music was not developed alone, but has been developed along with a variety of culture such as art, literature, architecture, and so on. That seems to be the reason why people decide to go to other countries, in order to gain experience living where the music itself was born."127

Kim has forged this position through having served on many juries, including the George Enescu International Competition, the International Tchaikovsky Competition for Young Musicians, the International Henryk Wieniawski Violin Competition, and the Queen Elisabeth Competition. Many Korean musicians have participated in these competitions and received prizes in recent decades, and some of them have been trained only in their home country. Kim

\footnotetext{
126 Jae Won Ryu, interview by author, Buyeo, Korea, August 7, 2012.

127 Young Ji Choi, "Violinist Min Kim," The Monthly Music Magazine Eumagchunchu 131 [July 2006$]$ : 45.
} 
feels there is an important distinction between Korean violinists in the competition: (1) the candidates who only trained in their country, and (2) the candidates who studied both in Korea and in another [Western] country. ${ }^{128}$

In Kim's opinion, the candidates who only learned violin in Korea have been well trained in general matters of violin playing, but often lack deeper artistry. Kim said "not in all cases, but generally speaking, they somewhat have a narrow expressiveness for the music. In other words, their [overall] musical line is weak. On the other hand, the candidates who have experience studying both in Korea and another country are much improved in this matter, and I guess that their experiences in another country have given them a better understanding of Western music in general."129 He also said that "an advantage of the Asian and Korean candidates is their well-trained and disciplined playing, and it seems to be because they are generally taught quite strictly compared with other countries' candidates." ${ }^{\prime 30}$ Kim said that "the foreign [Western] candidates seem to have the music blended into their blood; therefore, if Germans play Bach and Beethoven, their degree of expression in the music cannot be matched. It is the same thing when we play Korean traditional music, it will be much easier for us to express the feeling." 131 Therefore, Kim recommends that "those who aspire to become great soloists go early in their musical training to Western countries, where they can gain experience in all of the

\footnotetext{
128 Min Kim, interview by author, Buyeo, Korea, August 7, 2012.

129 Ibid.

130 Ibid.

131 Ibid.
} 
cultural and historical background relevant to their understanding of music."132

Concerning music as a career, Min Kim advises future musicians that "if you choose music, make sure that you continue to love it wholeheartedly. Since you decided to be a musician, try to keep your mind turning to music as a source of pleasure, satisfaction, and sense of accomplishment...if you do not feel these things with music, you will be unhappy whether you play well or not. I do not mean that you should just practice hard or go to concerts a lot - rather, once you have decided on music, try to pursue it with affection."133

Kim's contributions to the growth of chamber music in Korea are particularly distinctive. His affection for and contribution to chamber music throughout his entire musical life have helped to establish chamber music as one of the main music genres in Korea. In addition to this, the activities of the Korean Chamber Orchestra have furthered the development of chamber music, and the activities address the importance of studying chamber music.

Since the musical culture in Korea focuses mainly on soloists, many Korean musicians give their full attention to developing their abilities in this area, or to teaching and training other soloists. Therefore, Kim's devotion to chamber music makes him a pioneering figure in Korea's musical history. His achievements in chamber music consist not only of the Korean Chamber Orchestra's artistic and commercial success, but also in the increasing awareness on the part of Korean musicians that chamber music offers another possible area for them to develop their musical aspirations.

\footnotetext{
132 Min Kim, interview by author, Buyeo, Korea, August 7, 2012.

133 Ibid.
} 
Min Kim is definitely one of the most significant pioneers of chamber music in Korea, and he has contributed greatly to the importance of chamber music in the minds of his fellow musicians. Kim and the Korean Chamber Orchestra helped to acclimate people to the concept of ensemble playing, and through their efforts, chamber music became firmly rooted in the country. Now, it is the task of the younger generations to continue studying and performing chamber music. In this manner, younger musicians will continue Min Kim's important musical philosophy: moving the country's musical tradition forward, while giving constant effort and undying affection to their music. 


\section{Bibliography}

\section{Books}

Ahn, Yong Ku. 한 마리 새가 되어: 바이올리니스트 안용구의 77 년 음악일기 [As a bird: Violinist Yong Ku Ahn's 77 years life in music]. Gyungki-do, Korea: Hangilart, 2004.

Han, Sang Woo. 기억하고 식은 선구자들: 한국양악인물사 1 [The pioneers to be remembered: The historical figures of Western music in Korea 1]. Gyungki-do, Korea: Jisik-sanup, 2003.

Lee, Kang Sook, Choon Mi Kim, and Kyung Chan Min. 우리양악 100 년 [One hundred-year history of Western music in Korea]. Seoul: Hyeonamsa, 2001.

Noh, Dong Eun. 한국근대음악사 1 [Korean modern music history 1]. Gyungki-do, Korea: Hangilsa, 1995.

Song, Bang Song. 한국근대음악사연구 [The survey of Korean modern music history]. Seoul: Minsokwon, 2003.

\section{Dissertations}

Choi, Jeongseon. "Western Music in Korea with an Emphasis on Piano Compositions since 1970." DMA diss., University of Maryland, 1997.

Kim, Jasmine Jung-Im. "Western Music in Korea: Focused on 20th Century Flute Compositions by Korean Composers." DMA diss., University of Illinois at Urbana-Champaign, 2002.

\section{Encyclopedia Article}

Provine, Robert C., Okon Hwang, and Keith Howard. "Korea." In Grove Music Online. Oxford Music Online, http://www.oxfordmusiconline.com/subscriber/article/grove/music/45812 (accessed April 10, 2012). 


\section{Articles in Journals}

Ahn, Jin Soon. "우리 시대의 음악가를 찾아서, 바이올리니스트 이종숙" [This era's musician, violinist Jong Sook Lee]. String \& Bow, no. 57 (November 2003): 34-36.

Bae, Joo Young. "바이올리니스트 안병소 선생: 한국 최초의 바이올린 전문 연주가" [The first professional Korean violinist Byeong So Ahn]. The Monthly Music Magazine Eumagchunchu 150 (February 2008): 80-87.

Cho, Won-Kyung. "서울바로크합주단 2010 유럽투어" [The Korean Chamber Orchestra 2010 European trip]. String \& Bow, no. 138 (August 2010): 48-49.

Choi, Hye Jung. "김남윤: 연주자로서, 교육자로서의 그 열정" [Nam Yun Kim: Her passion as a violinist and teacher]. String \& Bow, no. 56 (October 2003): 28-33.

—. "바이올리니스트 김민과 선화예고 서지숙, 이은미 학생" [Violinist Min Kim and young violinists]. String \& Bow, no. 56 (October 2003): 68-71.

‥ "창단 40 주년 맞은 서울바로크합주단: 음악감독 및 리더 바이올리니스트 김민 인터뷰" [The 40th anniversary, the Korean Chamber Orchestra and its music director and leader Min Kim]. String \& Bow, no. 76 (June 2005): 26-27.

Choi, Young Ji. "바이올리니스트 김민" [Violinist Min Kim]. The Monthly Music Magazine Eumagchunchu 131 (July 2006): 44-45.

Gong, Yoon Jo. "예술, 나의 삶 나의 길: 바이올리니스트 김민" [Arts, my life my way: Violinist Min Kim]. Auditorium 112 (June 1993): 114-17.

Han, Sang Woo. "창단 40 주년 맞은 서울바로크합주단" [The 40th anniversary, the Korean Chamber Orchestra]. String \& Bow, no. 76 (June 2005): 22-25.

Han, Song Hee. "바이올리니스트 김민" [Violinist Min Kim]. The Monthly Music Magazine Eumagchunchu 141 (May 2007): 40-44.

Jeong, Hee Won. "바이올리니스트 김민, 3 년만에 리사이틀 갖는 영원한 음악청년" [Violinist Min Kim: Always a young musician]. String \& Bow, no. 98 (April 2007): 24-27.

Jeong, Kyung Hwa. "김민 바이올린 독주회" [Min Kim violin recital]. String \& Bow, no. 62 (April 2004): 44-45. 
Kim, Ji Soo. "바이올리니스트 김민: 2009 퀸 엘리자베스 콩쿠르 심사위원 위촉"

[Violinist Min Kim: The jury of the Queen Elisabeth Competition]. String \& Bow, no. 123 (May 2009): 54.

. "김민에게 듣는, 2009 퀸 엘리자베스 콩쿠르" [2009 Queen Elisabeth Competition, Min Kim]. String \& Bow, no. 125 (July 2009): 86-88.

—. "창단 45 주년 맞은, 서울바로크합주단" [The 45th anniversary, the Korean Chamber Orchestra]. String \& Bow, no. 131 (January 2010): 20-23.

Kim, Min "내일의 음악인에게" [To future musicians]. Auditorium 13 (March 1985): 138.

—. "살바토레 아카르도와의 협연을 마치고" [After playing with Salvatore Accardo]. Auditorium 34 (December 1986): 26-27.

ㄴ. "월드 필하모닉 오케스트라에서 만난 로린 마젤: 원숙한 예술성의 세계, 그 공감" [Lorin Maazel and World Philharmonic Orchestra: World of mature arts and its sympathy]. Auditorium 36 (February 1987): 16-20.

. "내가 만난 지휘자: 바이올리니스트 김민과 피에르 불레즈" [Conductor whom I met: Violinist Min Kim and Pierre Boulez]. String \& Bow, no. 84 (February 2006): 60-61.

Kim, Se Ra. "4 월의 음악인: 바이올리니스트 김민" [Monthly musician: Violinist Min Kim]. The Monthly Music Magazine Eumagchunchu 104 (April 2004): 88-89.

—. "창단 40 주년 맞은 서울바로크합주단" [The 40th anniversary of the Korean Chamber Orchestra]. The Monthly Music Magazine Eumagchunchu 118 (June 2005): 81-85.

Kook, Ji Yeon. "바이올리니스트 김민: 앙상블은 사람이 함께 모여 살듯" [Violinist Min Kim: Ensemble as people living together]. String \& Bow, no. 45 (November 2002): 18-21.

-. "My Life, My Music: 김민" [My life, my music: Min Kim]. String \& Bow, no. 111 (May 2008): 28-30.

—. "바이올리니스트 김민: 실내악홀의 메카를 꿈꾼다" [Violinist Min Kim: Dream a mecca of chamber hall]. String \& Bow, no. 140 (October 2010): 54-55.

—. "김민, 이대욱 베토벤 바이올린 소나타 전곡 연주회" [Min Kim and Dae Wook Lee, Beethoven violin sonata recital]. String \& Bow, no. 145 (March 2011): 26-29.

Lee, Ji Yeon. "학생 바이올리니스트 김민" [Young violinist Min Kim]. String \& Bow, no. 41 (July 2002): 66. 
Lee, Seung Eun. "한국을 움직인 음악가 시리즈 II: 바이올리니스트 김민" [Series of influential musicians in Korea II: Violinist Min Kim]. The Monthly Music Magazine Eumagchunchu 86 (October 2002): 28-31.

- "한국을 움직인 음악가 시리즈 4: 바이올리니스트 이종숙" [Series of influential musicians in Korea 4: Violinist Jong Sook Lee]. The Monthly Music Magazine Eumagchunchu 79 (March 2002): 20-23.

Lee, Sung Nam. "예술이 있는 곳: 바이올리니스트 김민" [The place where arts are: Violinist Min Kim]. Auditorium 60 (February 1989): 98-101.

Noh, Jin Kyung. "다양한 활동 펼치며 한국 바이올린계 발전에 헌신한 바이올리니스트 박민종 선생" [Violinist Min Jong Park's contributions to Korean violin music]. The Monthly Music Magazine Eumagchunchu 164 (April 2009): 118-26.

Noh, Seung Rim. "바이올리니스트 안용구 1: 절망속에서 발견한 음악이라는 희망" [Violinist Young Ku Ahn 1: A hope that was found through music in a time of despair]. Auditorium 251 (January 2005): 102-05.

—. "바이올리니스트 안용구 2: 좌절은 그를 꿈꾸게 했다" [Violinist Young Ku Ahn 2: The frustration made him turn to dreams]. Auditorium 252 (February 2005): 88-91.

—. "바이올리니스트 안용구 3: 음악, 분단을 넘어서다" [Violinist Young Ku Ahn 3: Music over ideology]. Auditorium 253 (March 2005): 94-97.

Paik, Sung Hyun. "바이올리니스트 김민" [Violinist Min Kim]. Auditorium 134 (April 1995): 72.

Park, Hye Rim. "바이올리니스트 정희석 선생: 한국 오케스트라 발전 위한 토대 구축" [Violinist Hee Seok Jeong: His contribution to the development of Korean orchestras]. The Monthly Music Magazine Eumagchunchu 152 (April 2008): 80-89.

Park, Jung Joon. "바이올리니스트 김민" [Violinist Min Kim]. Auditorium 178 (December 1998): 48-51.

Park, Ye In. "한국 실내악계 발전에 헌신한 바이올리니스트 최영우 선생" [Violinist Young Woo Choi's contributions to Korean chamber music]. The Monthly Music Magazine Eumagchunchu 175 (March 2010): 96-103.

-. "서울바로크합주단 음악감독 김민" [A director of the Korean Chamber Orchestra, Min Kim]. The Monthly Music Magazine Eumagchunchu 182 (October 2010): 42-43. 
Park, Yong Wan. "To Sir with Love: 바이올리니스트 김민 \& 윤경희" [To sir with love: Violinist Min Kim and Kyung Hee Yoon]. Auditorium 278 (April 2007): 82-84.

—. "바이올리니스트 김민: 내가 무대에 나설 때는" [Violinist Min Kim: When I am on the stage]. Auditorium 325 (March 2011): 90-91.

Ryu, Tae Hyung. "35 주년 맞은 서울 바로크 합주단의 리더 김민" [The 35th anniversary of the Korean Chamber Orchestra and its leader Min Kim]. Auditorium 200 (October 2000): 118.

—. "바이올리니스트 김민: 앙상블을 사랑한 멋쟁이 신사" [Violinist Min Kim: A gentleman who loved ensemble]. Auditorium 254 (April 2005): 40-44.

Son, Kwang Joo. "서울바로크합주단" [The Korean Chamber Orchestra]. Auditorium 15 (May 1985): 146-49.

Yang, Young Chan. "이 달의 음악가: 바이올리니스트 김남윤" [Monthly musician: Violinist Nam Yun Kim]. Auditorium 152 (October 1996): 72-75.

\section{Interviews}

Ahn, Ji Yoon. Interview by author, Buyeo, Korea, August 7, 2012.

—. E-mail message to author, October 28, 2012.

Choi, Jae Won. Interview by author, Buyeo, Korea, August 7, 2012.

Kim, Min. Interview by author, Buyeo, Korea, August 7, 2012.

Koenig, Robert. Interview by author, Buyeo, Korea, August 7, 2012.

Ryu, Jae Won. Interview by author, Buyeo, Korea, August 7, 2012.

Yoon, Kyung Hee. Interview by author, Buyeo, Korea, August 7, 2012. 


\section{Web Sites}

Korean Chamber Orchestra, "Profile," http://www.kco.or.kr/01-01.htm [accessed September 11, 2012].

Korean Chamber Orchestra, "CD Discography," http://www.kco.or.kr/03-03.htm [accessed September 20, 2012].

Korean Chamber Orchestra, "Music Director," http://www.kco.or.kr/eng/e01-02.htm [accessed September 22, 2012]. 